\title{
DETERMINANT OF PURCHASING DECISION AND LOYALTY OF THE CONSUMER OF WARDAH COSMETIC PRODUCTSIN BANDA ACEH, INDONESIA
}

\author{
Cut Rahmayanti, Permana Honneyta Lubis and Sorayanti Utami \\ Department of Management, University ofSyiah Kuala, Indonesia
}

http://doi.org/10.35409/IJBMER.2019.2428

\begin{abstract}
This study aims to test the effect of advertising appeals, celebrity endorser, and brand images on purchasing decisions and loyalty of the consumer of wardah cosmetic products in Banda Aceh. The population in this study is consumers who make decisions to buy the wardah products in Banda Aceh. The sample taken is as much as 150 respondents with purposive sampling technique. The results shows that the advertising appeal effects purchasing decision significantly, celebrity endorser effects purchasing decision significantly, brand image effects purchasing decision significantly, purchasing decision effects consumer loyalty significantly, advertising appeal effects consumer loyalty significantly, celebrity endorser effects consumer loyalty significantly, and brand image does not effect consumer loyalty significantly. The only rejected is the hypothesis 7 that is brand image does not effect consumer loyalty significantly. The causality results contribute to academic that these all can be updates for causality theories to be new premises, and can be develop in the next research by another researchers. The originality is in the form of the model, that this is an integration model from several ones in the previous research. These all findings has an implication to managers especially related to Wardah Cosmetic Products to pay more attention about the causality among variables in this research. This can be a reference to build the right policies and implement the strategies in the further. The limitation of this research lies in the number of variables and object.
\end{abstract}

Keyword: Advertising Appeals, Celebrity Endorser, Brand Images, Purchasing Decision, Loyalty.

\section{INTRODUCTION}

Along with the saturation of consumers with foreign brands, where the quality of local brands is starting to improve, then the pressure of the economic crisis makes some consumers return to local brands (Tjiptono, 2005).Cosmetic industry in Indonesia currently classified as solid or can be called strong.The growth of the domestic cosmetic industry gives a positive signal, because it continues to increase every year.

Wardah is the name of one local cosmetic product. Wardah is produced by PTI (PT Paragon Technology \& Innovation). with halal-labeled beauty cosmetics. Most consumers of cosmetic products choose wardah products as a beauty product or in other words wardah is a cosmetic 


\section{International Journal of Business Management and Economic Review}

Vol. 2, No. 06; 2019

ISSN: 2581-4664

product chosen by Indonesian consumers. Wardah product purchasing decisions is certainly influenced byseveral factors, which areadvertising appeal, celebrity endorser, and brand images. The first factor is the advertising appeal. Advertising appeal isalso can be carried out through or by celebrity to promote a product. The second factor is celebrity endorser. Today many product of manufacturers use celebrity endorser as a way to make their products soldout well in the market, such as Yamaha using the icon Valentino Rossi and Jorge Lorenzo, Christiano Ronaldo as ambassadors of "Clear" shampoo products, and many more producers use public figures services and even athletes as their product icon (Wiryawan and Pratiwi, 2009). The third factor is brand image. According to (Rangkuty, 2002), an image is the impression which is obtained in accordance with one's understanding and knowledge of something.

The strategy is carried out to provide customer satisfaction and maintain positive image of product within the consumer. The company continues to innovate by utilizing social media for product promotion and also using celebrities as supporters of its products and is often named as a brand ambassador of the product brand.

\section{LITERATURE}

\section{Advertising Appeal}

Advertising is one of the important tools in selling the name or brand of a product to consumers. According to(Kotler and Keller, 2018), advertising is any paid for non-personal presentation and promotion of ideas, goods, or services by a sponsor. The appeal of advertising aims to motivate consumers to take special actions that affect their attitude towards the product. Advertising is a supporting tool in promotional programs, therefore the advertising appeal is expected to increase the success of delivering messages to the target (Kazmi, 2009). According to (Wibisono, 2005)in (Tanoni, 2014), the ideal advertising are : can cause attention, interesting, can cause desire, and produce an action.

\section{Celebrity endorser}

Celebrities usually have fans (target audiences) who can translate or change to create a market target. They can provide valuable information when the celebrity aspect matches the product (Belch and Belch, 2003).(Kotler and Keller, 2018) explain that celebrity endorser are the use of speakers (source) as an interesting and popular figure in the advertising, it is a pretty creative ways to convey the message that the message can get higher attention and be remembered. Indicator of celebrity endorser according to (Ankasaniscara, 2012)in(Wenas, Tumbel and Parengkuan, 2014)namely: Explicit, Implicit, Imperative, and Co-presentational.

\section{Brand Image}

Brand image is a determinant in consumer decision making. According to (Kotler and Keller, 2018), the brand is a combination of symbols of goods or services of other vendors. According to (Shimp, 2013), brand image is as a type of association that appears in the minds of consumers when remembering a particular brand. Such associations can simply appear in the form of certain thoughts or images that are linked to a brand, as well as when we think about other people. Factors that influence a brand image according to(Kanuk and Schiffman, 1997)which are:Quality, Trusted, Usability, Service, Risk, Price, and Image. 


\section{International Journal of Business Management and Economic Review}

Vol. 2, No. 06; 2019

ISSN: 2581-4664

According to(Hoeffler and Keller, 2002)indicators of brand image include Professional impression, Modern impression, Serving all segments, and Attention to consumers.

\section{Purchase Decision}

The purchase decision according to (Andreasen and Kotler, 2002) is an action of a consumer to buy or not an product. Another understanding of purchasing decisions according to (Kanuk and Schiffman, 1997) is a person's decision where he chooses one of several available alternative choices. According to(Kotler and Keller, 2018)there are six indicators of purchasing decisions, which are : Product choice, Brand choice, Dealer choice, Purchase timing, Amount of Purchase, Payment Method

\section{Consumer Loyalty}

According to (Griffin, Phillips and Gully, 2016), consumers will be said to be loyal if a consumer shows regular buying behavior. Consumer loyalty can be created if consumers feel satisfaction with the productpurchased because it matches or even gets a value that is more than expected. According to (Hidayat, 2009)consumer loyalty is a consumer's commitment to a market based on a positive attitude and is reflected in a consistent repurchase. The Indicator of consumer loyalty are Trust, Emotion, Switching cost, Word of mouth, and Cooperation.

\section{RESEARCH METHOD}

The object is the consumer of Wardah cosmetic products located in Banda Aceh. The population in this study is consumers who make decisions to buy the products. The sample taken is as much as 150 respondents with purposive sampling technique, the criteria is the consumers in Banda Aceh, and as a user the products. Data collection is conducted using questionnaires. The questionnaire method is a series or list of questions arranged systematically, then sent to be filled out by the respondent. After filling in the questionnaire is sent back (Bungin, 2008).The questionnaire contains questions related to the influence of the advertising appeal, celebrity endorser, and brand image on purchasing decisions and their impact on consumer loyalty. Data is analyzed using structural equation modeling (SEM) with the help of the AMOS software. SEM is a set of statistical techniques that allow testing of a series of relatively complicated relationships simultaneously (Ferdinand, 2014).The appearance of a complicated model has the effect that in reality the management decision-making process is a complex process or is a multidimensional process with various patterns of tiered causality relationships. Therefore we need a model as well as an analytical tool that is able to accommodate the multidimensional research.SEM is able to enter latent variables into the analysis. Latent variables are unobserved concepts that are approximated by observed or measured variables obtained by respondents through data collection methods (survey, test, observation) and often called manifest variables (Ghozali, 2017). The Advantage of SEM application in management research is due to its capacity to confirm the dimensions of a concept or factors that are commonly used in the management as well as its ability to measure.

\section{RESULT}


International Journal of Business Management and Economic Review

Vol. 2, No. 06; 2019

ISSN: 2581-4664

The results of data processing for full analysis of SEM model are shown in Figure below.

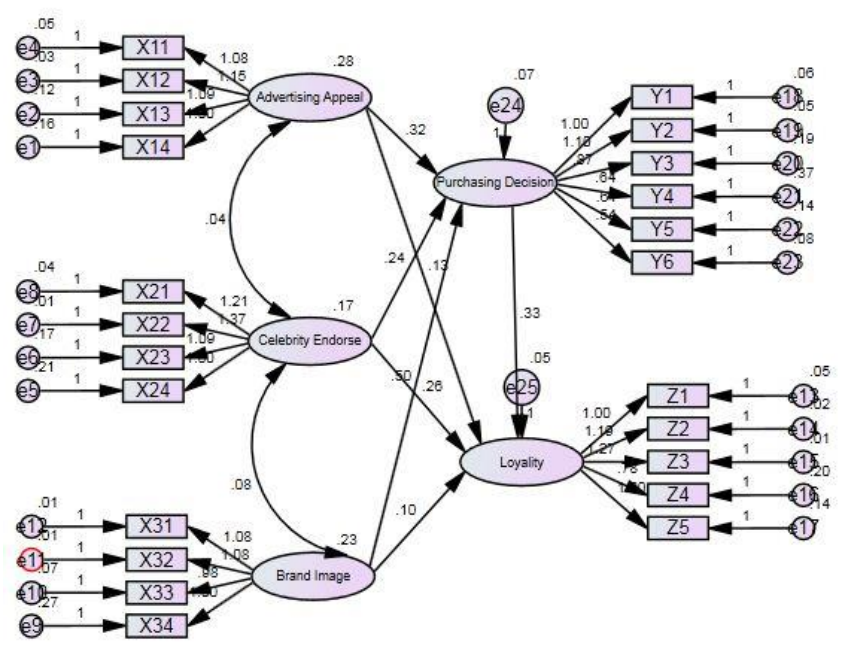

Figure 1. Structural Equation Model

Based on Figure 1, it is known the influence of variables namely the advertising appeal, celebrity endorser, brand image on purchasing decisions and also loyalty.

\section{Hypothesis Test}

Causality relationship can be seen in SEM processing result below.

\section{Tabel 1. Regression Weight}

\begin{tabular}{|lll|crr|}
\hline & & & Estimate & C.R. & P \\
\hline Purchasing decision & $<---$ & Advertising Appeal & 0.320 & 5.128 & 0.000 \\
Purchasing decision & $<---$ & Celebrity endorser & 0.241 & 2.937 & 0.003 \\
Purchasing decision & $<---$ & Brand Image & 0.504 & 5.740 & 0.000 \\
Loyalty & $<---$ & Advertising Appeal & 0.126 & 2.240 & 0.025 \\
Loyalty & $<---$ & Celebrity endorser & 0.261 & 3.578 & 0.000 \\
Loyalty & $<---$ & Celebrity endorser & 0.096 & 1.301 & 0.193 \\
Loyalty & $<---$ & Purchasing decision & 0.333 & 3.312 & 0.000 \\
\hline
\end{tabular}

Source : Primary Data Processed, (2018)

Based on the result of SEM analysis in Table 1 and statistical equations (1) and (2), the following results can be formulated: 


\section{International Journal of Business Management and Economic Review}

Vol. 2, No. 06; 2019

ISSN: 2581-4664

Purchasing Decision $=0.320$ Advertising appeal +0.241 Celebrity endorser+0.504Brand image Consumer Loyalty $=0.126$ Advertising appeal +0.261 Celebrity endorser $+0.096 \mathrm{Brand}$ image +0.333 Purchasing decision

\section{H1 is accepted}

The impact of advertising appeal on purchasing decisions is obtained by the CR value of 5.128 with a significance level of 0.000 . Thus it can be concluded that the advertising appeal affects the increase in purchasing decisions. The magnitude of the influence of the advertising appeal on the purchasing decision is 0.320 or $32.0 \%$. This indicates that the better the advertising appeal will have a positive and real influence on the increase in purchasing decisions. The results of the study are in line with the research conducted by Mukhlis Yunus and Syarifudin Chan (2015) who also concluded that advertising had an influence on interest.

\section{$\mathrm{H} 2$ is accepted}

The impact of celebrity endorser on purchasing decisions is obtained by the CR value of 2.937 with a significance level of 0.003 . Thus it can be concluded that the celebrity endorser influences the increase in purchasing decisions. The magnitude of the impact of celebrity endorser on purchasing decisions is 0.241 or $24.1 \%$. This indicates that the higher the celebrity endorser level will further increase the purchasing decision. The results of this study are in line with research conducted by (Ahmed, Farooq and Iqbal, 2014) who also concluded that advertising stars have a positive effect on purchasing decisions.

\section{$\mathrm{H3}$ is accepted}

The impact of brand image on purchasing decisions obtained a CR value of 5.740 with a significance level of 0.000 . Thus it can be concluded that brand image influences the increase in purchasing decisions. The magnitude of the impact of brand image on purchasing decisions is 0.504 or $50.4 \%$. This indicates that the higher the level of brand image will further increase purchasing decisions. The results of this study are in line with research conducted by (Alfanda et al., 2018) and (Ali, 2015) who also concluded that brand trust has a significant effect on consumer buying interest.

\section{H4 is accepted}

The impact of purchasing decisions on consumer loyalty obtained a CR value of 3.312 with a significance level of 0.000 . Thus it can be concluded that purchasing decisions affect consumer loyalty. The magnitude of the influence of purchasing decisions on consumer loyalty is 0.333 or $33.3 \%$. This indicates that with higher purchasing decisions it will have a direct influence on increasing consumer loyalty.

\section{H5 is accepted}

The impact of the advertising appeal on consumer loyalty obtained a CR value of 2.240 with a significance level of 0.025 . Thus it can be concluded that the advertising appeal has an effect on consumer loyalty. The magnitude of the impact of the advertising appealon consumer loyalty is 0.126 or $12.6 \%$. This indicates that the higher the advertising appeal will have a direct influence on increasing consumer loyalty. The results of this study are in line with the research conducted 


\section{International Journal of Business Management and Economic Review}

Vol. 2, No. 06; 2019

ISSN: 2581-4664

by (Mukhlis, 2015) which also concluded that the advertising appeal affects consumer loyalty.

\section{H6 is accepted}

The impact of celebrity endorser on consumer loyalty obtained a CR value of 3.578 with a significance level of 0.000 . Thus it can be concluded that the celebrity endorser has an impact on increasing consumer loyalty. The magnitude of the impact of celebrity endorser on consumer loyalty is 0.261 or $26.1 \%$. This indicates that the higher the celebrity endorser that is owned will have an impact on increasing consumer loyalty. The results of this study are in line with the research conducted by (Mukhlis, 2015) which also concluded that celebrity endorser influence consumer loyalty.

\section{$\mathrm{H} 7$ is accepted}

The impact of brand image on consumer loyalty obtained a CR value of 1.301 with a significance level of 0.193 . Thus it can be concluded that the brand image does not have an impact on increasing consumer loyalty. The results of this study are not in line with the research conducted by (Lubis, 2016) which concluded that brand image influences consumer loyalty.

Furthermore, the test results of each hypothesis above is presented briefly in Table below about the hypothesis conclusions.

Table 2.Conclusion of Hypothesis

\begin{tabular}{|c|c|c|c|c|}
\hline No & Hypothesis & $\begin{array}{c}\text { CRCut } \\
\text { off }>1.96\end{array}$ & $\begin{array}{c}\text { P Value } \\
\text { Cut off }<0.05\end{array}$ & Result \\
\hline 1 & $\begin{array}{l}\text { Advertising Appeal (X1) effects } \text { Purchasing Decision (Y) } \\
\text { significantly }\end{array}$ & 5.128 & $\begin{array}{c}0.000 \\
(\mathrm{Sig},<5 \%)\end{array}$ & $\mathrm{H}_{1}$ Accepted \\
\hline 2 & Celebrity endorser (X2) effects Purchasing Decision (Y) significantly & 2.937 & $\begin{array}{c}0.003 \\
(\mathrm{Sig},<5 \%)\end{array}$ & $\mathrm{H}_{2}$ Accepted \\
\hline 3. & Brand Image (X3) effects Purchasing Decision(Y) significantly & 5.740 & $\begin{array}{c}0.000 \\
(\operatorname{Sig},<5 \%)\end{array}$ & $\mathrm{H}_{3}$ Accepted \\
\hline 4 & Purchasing Decision (Y) effects Consumer Loyalty (Z) significantly & 3.312 & $\begin{array}{c}0,000 \\
(\mathrm{Sig},<5 \%)\end{array}$ & $\mathrm{H}_{4}$ Accepted \\
\hline 5 & Advertising Appeal (X1) effects Consumer Loyalty (Z) significantly & 2.240 & $\begin{array}{c}0.025 \\
(\mathrm{Sig},<5 \%)\end{array}$ & $\mathrm{H}_{5}$ Accepted \\
\hline 6 & Celebrity endorser (X2) effects Consumer Loyalty (Z) significantly & 3.5778 & $\begin{array}{c}0.000 \\
(\mathrm{Sig},<5 \%)\end{array}$ & $\mathrm{H}_{6}$ Accepted \\
\hline 7 & $\begin{array}{l}\begin{array}{l}\text { Brand Image (X3) does not effect } \\
\text { significantly }\end{array} \\
\text { Consumer Loyalty (Z) }\end{array}$ & 1.301 & $\begin{array}{c}0.193 \\
(\operatorname{Sig},<5 \%)\end{array}$ & $\begin{array}{c}\mathrm{H}_{7} \\
\text { Rejected }\end{array}$ \\
\hline
\end{tabular}

Source : PrimaryData Processed, (2018)

Based on table 2 it can be explained that the advertising appeal, celebrity endorser, and brand image effect the purchase decision. Others, the advertising appeal, celebrity endorser, and purchasing decisions affect the consumer loyalty. While the brand image does not affect the consumer loyalty. 
Vol. 2, No. 06; 2019

ISSN: 2581-4664

\section{CONCLUSION}

The result figures the advertising appeal effects purchasing decision significantly, celebrity endorser effects purchasing decision significantly, brand image effects purchasing decision significantly, purchasing decision effects consumer loyalty significantly, advertising appeal effects consumer loyalty significantly, celebrity endorser effects consumer loyalty significantly, and brand image does not effect consumer loyalty significantly. The only rejected is the hypothesis 7 that is brand image does not effect consumer loyalty significantly. The causality results contribute to academic that these all can be updates for causality theories to be new premises, and can be develop in the next research by another researchers. The originality is in the form of the model, that this is an integration model from several ones in the previous research. These all findings has an implication to managers especially related to Wardah Cosmetic Products to pay more attention about the causality among variables in this research. This can be a reference to build the right policies and implement the strategies in the further. The limitation of this research lies in the number of variables and object.

\section{REFERENCE}

Ahmed, N., Farooq, O. and Iqbal, J. (2014) 'Credibility of Celebrity Endorsement and Buying Intentions an Evidence from Students of Islamabad, Pakistan', International Letters of Social and Humanistic Sciences, 20(January), pp. 1-13. doi: 10.18052/www.scipress.com/ilshs.20.1.

Alfanda, R. et al. (2018) 'Celebrity Endorsement as Moderating Variable on the Relationship between Loyalty and Corporate Credibility of Travel Companies in Aceh', International Journal of Contemporary Research and Review, 9(4), pp. 20726-20734. doi: https://doi.org/10.15520/ijcrr/2018/9/04/500.

Ali, S. M. (2015) 'ISSN : 2338-2929 Persepsi Konsumen Terhadap Model Iklan Sepeda Motor Merek Yamaha di Kota Banda Aceh', Jurnal Ekonomi Manajemen dan Bisnis, 3(2006), pp. 504521.

Andreasen, A. R. and Kotler, P. T. (2002) Strategic Marketing for Non-Profit Organizations. United Kingdom: Pearson.

Ankasaniscara, P. (2012) Analisis Pengaruh Celebrity Endrosement pada Brand Image terhadap Keputusan Pembelian Studi Kasus: Pete Says Denim. Universitas Indonesia.

Belch, G. E. and Belch, M. A. (2003) Advertising and Promotion An Integrated Marketing Communications Perspective. Sixth Esti. New York: The McGraw-Hill. doi: 10.1007/978-14302-4408-0_4.

Bungin, B. (2008) Analisis Data Penelitian Kualitatif. Jakarta: Raja Grafindo.

Ferdinand, A. (2014) Metode Penelitian Manajemen. Edisi 5. Semarang: Universitas Diponegoro.

Ghozali, I. (2017) Model Persamaan Struktural, Konsep dan Aplikasi dengan Program AMOS 24 Update Bayesian SEM. Edisi 7. Semarang: Badan Penerbit Universitas Diponegoro.

Griffin, R. W., Phillips, J. M. and Gully, S. M. (2016) Organizational Behavior: Managing 


\section{International Journal of Business Management and Economic Review}

Vol. 2, No. 06; 2019

ISSN: 2581-4664

People and Organizations. 12 Th Edit. Boston: Cengage Learning.

Hidayat, R. (2009) 'Pengaruh Kualitas Layanan, Kualitas Produk dan Nilai Nasabah Terhadap Kepuasan dan Loyalitas Nasabah Bank Mandiri', Jurnal Manajemen dan Kewirausahaan, 11(1), pp. 59-72. doi: https://doi.org/10.9744/jmk.11.1.pp.\%2059-72.

Hoeffler, S. and Keller, K. L. (2002) 'Building brand equity through corporate societal marketing', Journal of Public Policy and Marketing, 21(1), pp. 78-89. doi: 10.1509/jppm.21.1.78.17600.

Kanuk, L. L. and Schiffman, L. G. (1997) Consumer Behavior. New Jersey: Prentice Hall.

Kazmi, S. H. H. (2009) Consumer Behaviour \& Marketing Communication. Jakarta: Excel Books.

Kotler, P. and Keller, K. L. (2018) Marketing Management, Global Edition. 15th editi. Harlow, United Kingdom: Pearson.

Lubis, A. R. (2016) 'The Influence of Online Service Quality, Brand Image, and Trust in Satisfaction and Its Impact on Loyalty', Jurnal manajemen Pascasarjana Unsyiah2, 5(1).

Mukhlis (2015) 'Effects of Advertising, Exhibitions, and Events on Tourist Awareness and Their Impact on Interest', Jurnal Manajemen Pascasarjana Unsyiah, 4(2).

Rangkuty, F. (2002) Measuring customer satisfaction. Jakarta: Gramedia Pustaka Utama.

Shimp, T. A. (2013) Advertising, Promotion, adn Other Aspect of Integrated Marketing Communivations. 7th Editio, Journal of Chemical Information and Modeling. 7th Editio. USA: Thomson South-Western. doi: 10.1017/CBO9781107415324.004.

Tanoni, R. V. (2014) 'Merek Dan Sikap Pada Minuman Isotonic Mizone Di Surabaya', Jurnal Ilmu dan Riset Manajemen, 1(2), pp. 1-7.

Tjiptono, F. (2005) Brand management \& Strategy. Yogyakarta: Andi Publisher.

Wenas, R., Tumbel, A. and Parengkuan, V. (2014) 'Analisis Pengaruh Brand Image Dan Celebrity Endorsment Terhadap Keputusan Pembelian Produk Shampo Head and Shoulders Di 24 Mart Manado', Jurnal Riset Ekonomi, Manajemen, Bisnis dan Akuntansi, 2(3), pp. 17921802.

Wibisono, A. (2005) Pengaruh Sikap Atas Iklan Sabun Mandi Padat Merek Lifebuoy terhadap Sikap Atas Merek Sabun Mandi Padat Lifebuoy di Kalangan Mahasiswa Universitas Katolik Widya Mandala Surabaya. Unika Widya Mandala Surabaya.

Wiryawan, D. and Pratiwi, A. (2009) 'Analysis of the Effects of Celebrity Endorsers on Brand Image on Prepaid XL Bebas Card Product Ads in Bandar Lampung, Jurnal Bisnis dan Manajemen, 5(3). 